For citation: Thanh D. V. (2019). Macro-econometric Model for Medium-Term Socio-Economic Development

Planning in Vietnam. Part 2: Application of the Model. Ekonomika Regiona [Economy of Region], 15(3), 695-706

doi 10.17059/2019-3-6

UDC: 338.27

JEL: C51, C53, E17

D. V. Thanh

Nguyen Tat Thanh University (Ho Chi Minh, Vietnam; e-mail: dvthanh@ntt.edu.vn)

\title{
MACRO-ECONOMETRIC MODEL \\ FOR MEDIUM-TERM SOCIO-ECONOMIC DEVELOPMENT PLANNING IN VIETNAM. PART 2: APPLICATION OF THE MODEL ${ }^{1}$
}

Vietnam is building the market economy while still determining development plans as important tools for managing and operating the economy. In response to the challenges posed by economic globalization, the Vietnamese government has established the necessity to promote the macro economic analysis and forecasting for ensuring the government's policy-making and socio-economic development planning. A macro-econometric model for medium-term socio-economic development planning in Vietnam was built and called the Vietnam's model. This paper answers the following questions: which key applications can be implemented using the model? What is the model's quality of forecasts? The paper briefly presents how to forecast using the model. Then, I demonstrate how to synthesise, validate, balance and combine the model's forecasts implemented by the ministries and provincial authorities, and with application of judgemental methods. I establish the ways to build baseline and target forecast scenarios. The paper shows how the model can evaluate shocks and economic policies. Additionally, I demonstrate how to adjust planned target indicators in the process of implementing the medium-term socio-economic development plan. The article also evaluates the accuracy of the model's ex-ante forecasts. Finally, I apply the model's ex-ante forecasts for producing the official forecasts for building the Socio-Economic Development Plan (SEDP) at national scope for the period from 2016 to 2020.

Keywords: economic modelling, macro econometric models, forecasting models, models and applications, judgmental method, socio-economic development planning, strategic planning, forecasting procedures, forecasting scenarios, medium-term forecast

\section{Introduction}

Within the framework of the state-level research cooperation project in the form of a protocol between the Governments of Vietnam and the Russian Federation entitled «Research on medium-term socio-economic forecasting methodologies in the Russian Federation and its applicability to Vietnam» [1], a macro econometric model for medium-term (five-year) socio-economic development planning in Vietnam (called the Vietnam's model) was built. I have introduced the goals, requirements and structure of this model in [2].

The Vietnam's model was developed based on main ideas of the forecasting procedures and the system of forecast models for strategic planning employed in the Russian Federation [3, 4, 5, 6, 7, $8,9]$. It was also improved with the help of other countries' macroeconomic models $[10,11,12]$.

However, key applications of the Vietnam's model have not been introduced yet. Moreover, the accuracy of the model's forecasts is yet to be

\footnotetext{
${ }^{1}$ ( ) Thanh D. V. Text. 2019.
}

assessed. Continuing the research presented in the work [2], this paper will introduce key applications of the Vietnam's model and evaluate the model's forecast quality by comparing the model's ex-ante forecasts using two established forecast scenarios with actual statistical data for 2016 and 2017. I created two forecast scenarios based on two different sets of assumptions determined in the same way as in ${ }^{2}$ [3].

The paper has the following structure: section 2 will introduce domestic and foreign factors affecting the socio-economic development of Vietnam in medium - term. These factors are exogenous variables of the Vietnam's model used to set up forecast scenarios. Section 3 will present some key applications of the model. Section 4 will evaluate the model's forecast accuracy. Section 5 is the final section that will present some conclusions and discussions.

\footnotetext{
${ }^{2}$ Putin, V. (2009). Decree on the order of making forecasts of socio-economic development of Russian Federation, No. 596, July 22, 2009. (In Russ.)
} 


\section{Foreign and Domestic Factors in the Vietnam's Model}

The foreign and domestic factors of the Vietnam's model in [2] are represented by exogenous variables demonstrated in Table 1 . The variables are used to establish the conditions for creating forecast scenarios.

\section{Application of the Model}

In this section, the paper will introduce some key applications using the Vietnam's model.

\subsection{Making Forecasts Using the Model}

I presented the issues that the Vietnam's model can forecast in the previous work [2]. It should be noted that this model can generate the systematic, comprehensive and detailed forecasts for five-year and annual socio-economic development planning in Vietnam.

Making forecasts using the Vietnam's model is an iterative process. It starts with the Production and GDP block [2] where gross domestic product $(G D P)$ of whole economy as well as of the pri-

Foreign and domestic factors in the Vietnam's model

\begin{tabular}{|c|c|c|c|}
\hline № & Foreign factors & Units & Sources \\
\hline 1 & World price of raw oil & current USD/barrel & NIGEM-forecasted by NIER ${ }^{* 1}$ \\
\hline 2 & Price of raw materials for the primary industry & current USD/ton & NIGEM-forecasted by NIER \\
\hline 3 & World price of rice & current USD/ton & OECD Statistical Office \\
\hline 4 & GDP of the world economy & billions of constant USD & $\begin{array}{l}\text { NIGEM - calculated, } \\
\text { forecasted by NIER }\end{array}$ \\
\hline 5 & Total world trade & billions of constant USD & $\begin{array}{l}\text { NIGEM - calculated, } \\
\text { forecasted by NIER }\end{array}$ \\
\hline 6 & World import growth rate, & $\%$ & $\mathrm{IMF}^{* 2}$ \\
\hline 7 & Export price index of China & Deflator base 1 in last year & $\begin{array}{l}\text { NIGEM - calculated, } \\
\text { forecasted by NIER }\end{array}$ \\
\hline 8 & $\begin{array}{l}\text { The import growth rates of the world and of } \\
\text { Vietnamese merchandises and services by } 17 \text { major } \\
\text { trade partners of the economy }\end{array}$ & $\%$ & IMF \\
\hline & Domestic factors & & \\
\hline 9 & Nominal exchange rate of Dong to USD & current Dongs/USD & State Bank \\
\hline 10 & Government investment (Public investment) & $\begin{array}{l}\text { billions of constant } 2010 \\
\text { Dongs } \\
\end{array}$ & $\begin{array}{l}\mathrm{GSO}^{* 3} \& \text { calculated, } \\
\text { forecasted by the author }\end{array}$ \\
\hline 11 & 12-month lending rate & $\%$ & State Bank \\
\hline 12 & Credit to the private sector/GDP at current prices & $\%$ & $\begin{array}{l}\mathrm{ADB}^{* 4} \& \text { calculated, } \\
\text { forecasted by the author }\end{array}$ \\
\hline 13 & Rate of devaluation of DONGS & $\%$ & State Bank \\
\hline 14 & M2/GDP at current prices & $\%$ & GSO \\
\hline 15 & Foreign direct investment (FDI) $)^{\star_{5}}$ & $\begin{array}{l}\text { billions of constant } 2010 \\
\text { Dongs }\end{array}$ & $\begin{array}{c}\mathrm{MPI}^{* 6} \& \text { calculated by the } \\
\text { author }\end{array}$ \\
\hline 16 & $\begin{array}{l}\text { Percentage of total budget revenue spent on } \\
\text { education and training, health care, social security, } \\
\text { defence and national security. }\end{array}$ & $\begin{array}{l}\% \text { of total budget revenue of } \\
\text { current Dongs }\end{array}$ & Ministry of Finance (MOF) \\
\hline 17 & $\begin{array}{l}\text { The depreciation rates by whole economy and by } \\
\text { economic sectors }\end{array}$ & $\%$, unchanged & GSO \\
\hline 18 & $\begin{array}{l}\text { Electricity prices for production, business, civil use, } \\
\text { public service activities, etc. }\end{array}$ & constant 2010 Dongs/kwh & $\begin{array}{l}\text { MOIT }^{* 7} \& \text { calculated, } \\
\text { forecasted by the author }\end{array}$ \\
\hline 19 & $\begin{array}{l}\text { Share in Vietnamese export to the } 17 \text { major trade } \\
\text { partners }\end{array}$ & $\%$ of total export of Vietnam & $\begin{array}{l}\text { GSO \& calculated, forecasted } \\
\text { by the author }\end{array}$ \\
\hline
\end{tabular}

${ }^{* 1}$ NIER - National Institute of Economic and Social Research, UK. National Institute Global Econometric Model (NiGEM). http:// www.niesr.ac.uk/ (Date of access: 20.10.2015).

${ }^{* 2}$ IMF - International Monetary Fund. http://www.imf.org/ (Date of access: 15.10.2015).

${ }^{* 3}$ GSO - General Satistical Office of Vietnam. http://www.gso.gov.vn.

${ }^{*} \mathrm{ADB}$ - Asian Development Bank, https://www.adb.org/ (Date of access: 26.10.2015).

${ }^{*}$ FDI reflects the impact of domestic and foreign environment on socio-economic development.

${ }^{* 6}$ MPI - Ministry of Planning and Investment.

${ }^{* 7}$ MOIT - Ministry of Industry and Trade. 
mary, secondary and tertiary industries are forecasted in accordance with the demand approach. Then, it follows the next blocks in the order as indicated in [2]. Finally, it returns to the Production and GDP block to forecast the GDP in accordance with the supply approach. This iterative process stops when the GDP forecasted in accordance with the supply approach is approximately equal to the GDP forecasted in accordance with the demand approach. In this process, it is possible to adjust outputs of several blocks. However, as these outputs are the inputs of some another blocks, it is also possible to ensure the fit and balance of the forecasts as well as to stop the forecasting process.

\subsection{Synthesising, Validating, Combining and Balancing Forecasts Obtained from Many Sources Using the Model}

The Vietnam's model is used to synthesise and validate forecasts implemented by the ministries and provincial authorities. The most effective method is to use techniques of combining forecasts obtained from the Vietnam's model, from other statistical models and from this model with application of judgemental methods. Then such combination is implemented for each block of the model.

Combining the forecasts obtained from different models often produces a forecast that performs better than the best forecast obtained from an individual model [13]. That is why forecasts' combination is especially effective for improving the forecast accuracy when different forecasting methods are available. In order to improve the accuracy of socio-economic forecasts in the context of rapid and unpredictable changes of socio-economic situations in the country and abroad, and of economic policies frequently revised and adjusted, combining forecasts from different statistical models as well as from statistical models with application of judgmental methods are very necessary. One can refer to the forecasting methods of judgment mentioned in $[14,15,16]$.

The methods and principles of combining forecasts can be found out in $[17,18]$. According to the works $[19,20]$, during the process of combining forecasts from statistical models using judgmental methods, application of statistical models is preferable as a starting point. Then, forecasters apply judgmental adjustments to the forecasts generated by the statistical models. Some authors [20] claim that the relationship between judgmental and statistical forecasts based on field (rather than on laboratory and judgmental) revisions work best when forecasters have strong domain knowledge. Domain knowledge significantly im- proves forecast's accuracy over statistical models $[21,22]$. The paper [22] highlights the importance of adding domain knowledge to statistical models in the form of both anecdotal program knowledge and specific quantitative adjustments to account for expected policy changes. Domain knowledge is best utilized when it is incorporated into the forecast in a more structured manner.

The Vietnam's model is a large model related to the knowledge of many different domains. In [2] I decomposed the model into the blocks based on the nature of economic theories. Each domain knowledge in the model is primarily concerned with a state management ministry (as a main subject of socio-economic development planning). Hence, the decomposition has become a strategy to facilitate the combination of forecasts obtained from the Vietnam's model and from statistical models built by other subjects of socio-economic development planning as well as from this model with application of judgemental methods

In fact, forecasts obtained from some blocks of the Vietnam's model have been combined with forecasts from related state management ministries for improving the forecast accuracy. Currently, there are different ways to combine forecasts from many statistical models [17]. Thus, the selection of a way of combining forecasts from each block in the Vietnam's model depends on each specific block.

The forecasts balancing mainly focuses on checking three aspects. Firstly, it analyses the important identities of macro economy, including the identities expressing the relationships between income per capita, population and GDP, between productivity, employment and GDP, etc. Secondly, the forecasts balancing considers the stability of some important elasticities, such as the elasticities between the budget revenue and GDP; between the employment and GDP; between the consumed electricity and GDP, etc. Thirdly, it examines the fit between the GDPs forecasted under the two approaches of supply and demand.

\subsection{Building Forecast Scenarios}

The conditions for setting up a forecast scenario for socio-economic development planning for the period from 2016 to 2020 are a set of assumption values of domestic and foreign factors at this stage. The assumption values in general are the forecasts of domestic and foreign factors.

From the experience of the Russian Federation ${ }^{1}$, forecast scenarios for medium-term socio-eco-

\footnotetext{
${ }^{1}$ Putin, V. (2009). Decree on the order of making forecasts of socio-economic development of Russian Federation, No. 596,
} 
nomic development planning in Vietnam also include at least two following scenarios [1].

Baseline scenario. The conditions for setting up this scenario are defined as follows: if the forecasts of the foreign factors in the next planning period undertaken by some international agencies are not significantly different, then they will be obtained from the National Institute of Social and Economic Research of the United Kingdom via using NiGEM ${ }^{1}$ software. If the forecasts of the foreign factors have significant differences, then the forecasters will adjust them based on the forecasts of these international agencies. The changes of the domestic factors are assumed to be nearly identical to the rules for the planning year and the previous years.

In this paper, the foreign factors are forecasted by the International Agencies as indicated in Table 1. I forecasted the domestic factors using the autoregressive model of order $\mathrm{p}$ with the trend $\operatorname{AR}(p)$. Vietnam has not yet implemented the Free Trade Agreement of Vietnam - the European Union (EVFTA) and the Comprehensive and Progressive Agreement for Trans Pacific Partnership (CPTPP). In other words, it has been assumed that the use and effectiveness of resources has not changed much.

Target scenario. In target scenarios, forecasts of foreign factors are the same as in the baseline scenario. However, domestic factors are forecasted according to: the Party and State's socio-economic development objectives, economic policies relating to restructuring the economy, the requirements for macro-economic stability, the promotion of investment and the allocation of resources, the budget balance and the process of participation and implementation of the EVFTA and CPTPP Agreements, etc. In other words, target scenarios emphasise the effective use of resources. The changes in the use do not follow rules established from historical data. In the paper, I forecasted the domestic factors demonstrated in Table 1.

The main idea of creating the two scenarios in the aforementioned way is based on the experience of setting up the two forecast scenarios for strategic planning in the Russian Federation ${ }^{2}$.

The following tables introduce forecasts of domestic and foreign factors for the period from 2016 to 2020 for the two scenarios mentioned above. Specifically, Tables 2, 3 include the forecasts of foreign factors and Tables 4, 5 include the

\footnotetext{
July 22, 2009. (In Russ.)

${ }^{1}$ http://www.niesr.ac.uk/ (Date of access: 20.10.2015).

${ }^{2}$ Putin, V. (2009). Decree on the order of making forecasts of socio-economic development of Russian Federation, No. 596, July 22, 2009. (In Russ.)
}

forecasts of domestic factors for the baseline scenario while the Tables 6, 7 include the forecasts of domestic factors for the target scenario. In the second scenario, the EVFTA and CPTPP agreements are assumed to be implemented by the end of 2018 and the impact of these agreements on the Vietnamese economy was referenced in the literature ${ }^{3}$.

Comparison of tables 4 and 6 tables and of tables 5 and 7 shows that the values of domestic factors such as 12-month lending rate, depreciation rates by whole economy and by economic sectors, and the electricity prices for production, business, civil use, public service activities are the same for the two target and baseline scenarios. The difference in the values of the most crucial domestic factors in the target and baseline scenarios is shown in Figure 1.

Table 8 introduces two scenarios of forecasts obtained by using the Vietnam's model on the two sets of values of the foreign and domestic factors for the two baseline and target scenarios, respectively. These forecasts were obtained using only the Vietnam's model, without using any forecast methods. Figure 2 illustrates the forecasted difference in the growth rate of some important economic indicators of the target scenario compared to the baseline scenario.

In addition to two forecast scenarios for medium-term socio-economic development planning described above, it is possible to create other forecast scenarios according to different value sets of the foreign and domestic factors by using the Vietnam's model,.

\subsection{Evaluating Impacts of Shocks and Economic Policies}

I tested the sensitivity of exogenous variables used in the all blocks (foreign and domestic factors) as well as only in some blocks of the Vietnam's model. The signs of the estimated parameters in the behavioural equations are consistent with macro-economic theories. Evaluation of the impact of single shocks (belonging to an exogenous variable) or synthetic shocks (belonging to many exogenous variables) is done in the same way. This way of evaluation is similar to the way of creating and comparing a forecast scenario with the baseline scenario as presented above.

\footnotetext{
${ }^{3}$ EroChamVn. Trade \& Inverstment and Recomendations. The Whitebook 2017 (Overview, Part 1, Part 2 ). http://www. eurochamvn.org/Whitebook (Date of access: 25.10.2017); World Bank (2018). Economic and Distributional Impacts of Comprehensive and Progressive Agreement for Trans-Pacific Partnership: the case of Vietnam. Washington, DC: World Bank. License: Creative Commons Attribution CC BY 3.0 IGO.
} 


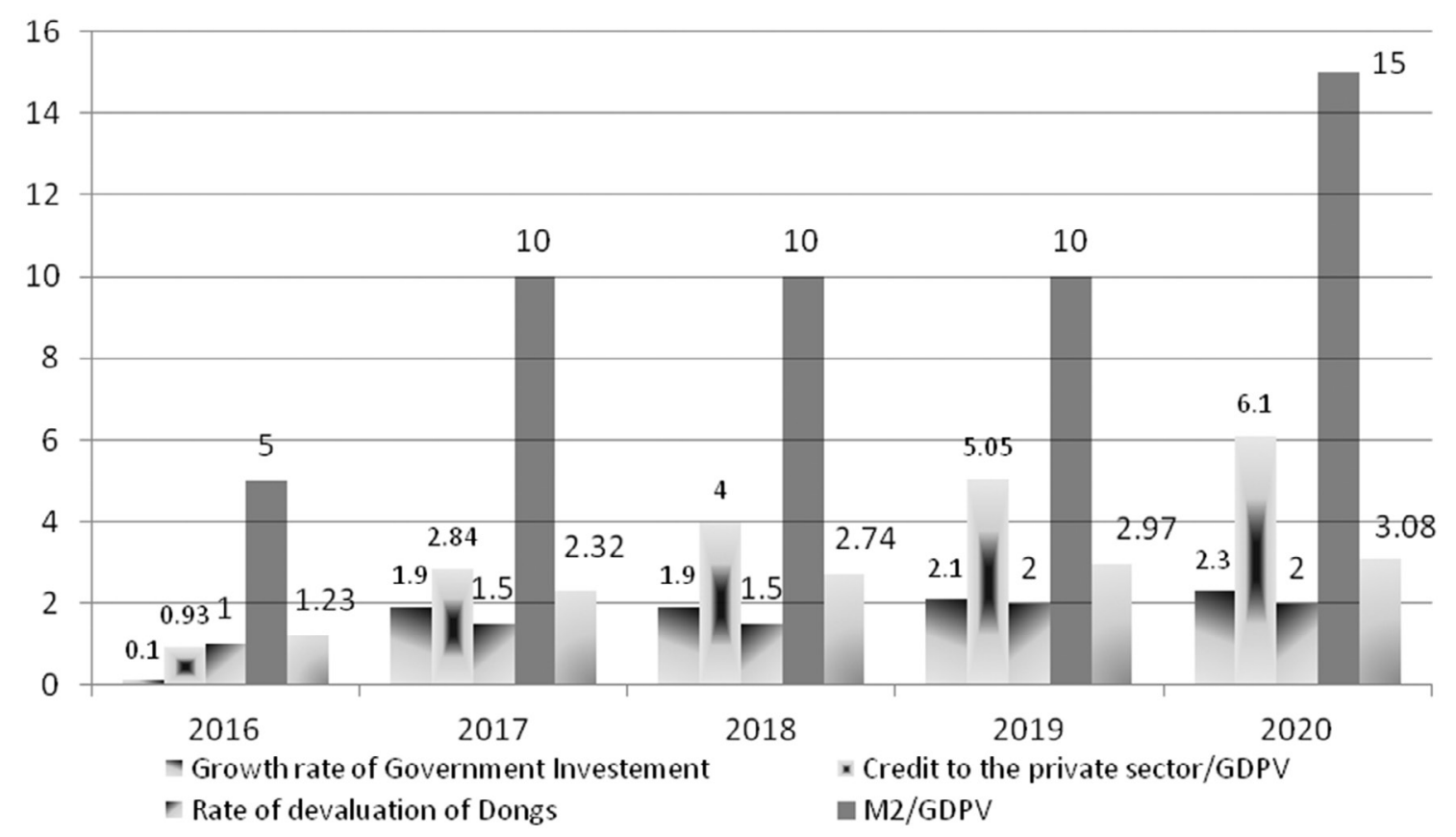

Fig. 1. Forecast differences of some domestic factors (target S. vs. baseline S.: \% point)

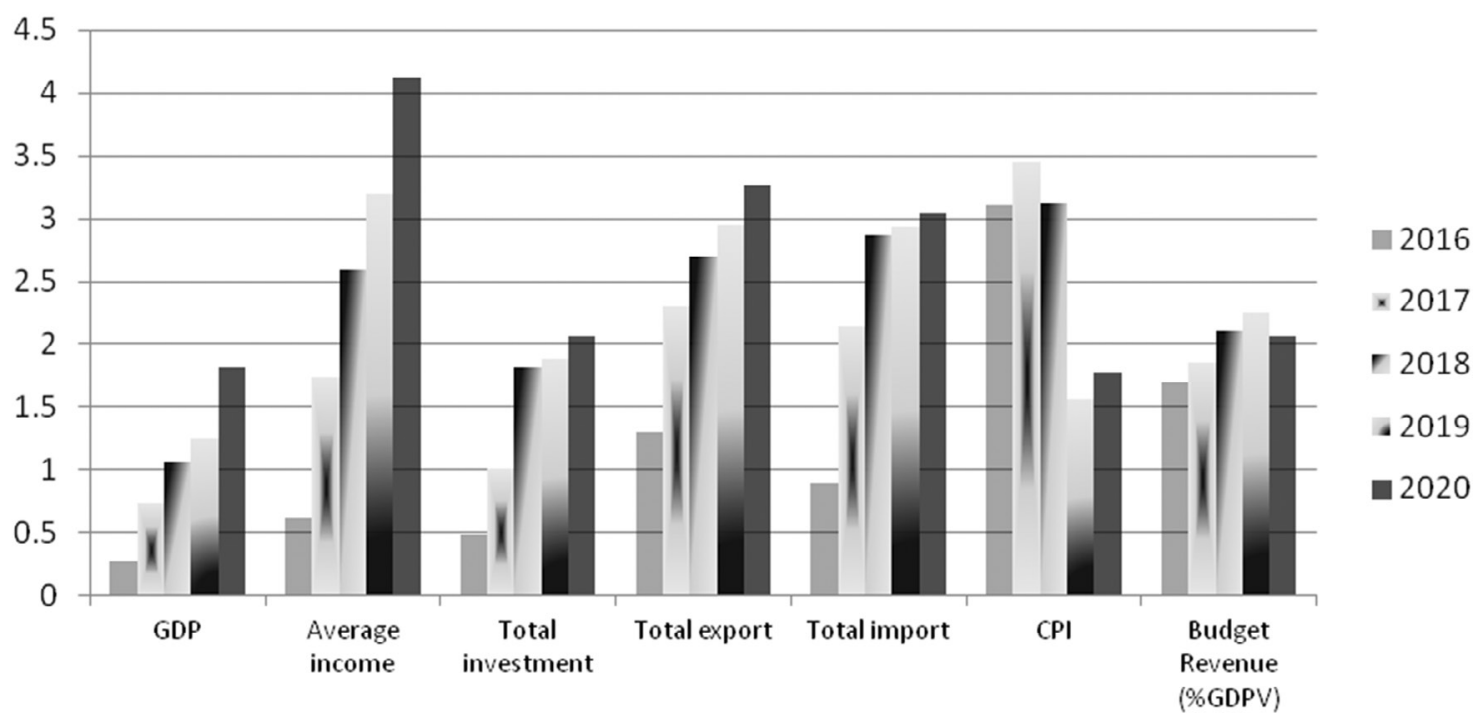

Fig. 2. Target scenario forecasts vs. Baseline scenario ones (\% point)

Table 2

Forecasts of foreign factors for the period from 2016 to 2020

\begin{tabular}{|l|c|c|c|c|c|c|c|c|}
\hline \multicolumn{1}{|c|}{ Foreign factors } & Unit & $\mathbf{2 0 1 5 e}$ & $\mathbf{2 0 1 6 f}$ & $\mathbf{2 0 1 7 f}$ & $\mathbf{2 0 1 8 f}$ & $\mathbf{2 0 1 9 f}$ & $\mathbf{2 0 2 0 f}$ & Source \\
\hline Price of crude oil/ barrel & USD & 46 & 35 & 47 & 55 & 58 & 60 & NIESR $^{*}$ \\
\hline Price of rice/ ton & USD & 356.648 & 395.157 & 400.123 & 407.771 & 409.748 & 412.302 & OECD \\
\hline World GDP & Bil. USD & 105615.4 & 109121.9 & 113257.6 & 117561.4 & 122499 & 127521.4 & NIESR \\
\hline Growth rate & $\%$ & 3.1 & 3.32 & 3.79 & 3.8 & 4.2 & 4.1 & \\
\hline Total world trade & Bil. USD & 48055.68 & 50708.36 & 53370.55 & 56353.96 & 59425.25 & 62628.27 & NIESR \\
\hline Growth rate & $\%$ & 5.38 & 5.52 & 5.25 & 5.59 & 5.45 & 5.39 & \\
\hline $\begin{array}{l}\text { Price of raw materials for } \\
\text { the primary industry/ton }\end{array}$ & USD & 300.7477 & 370.269 & 399.5913 & 396.864 & 402.3663 & 412.8691 & NIESR \\
\hline $\begin{array}{l}\text { Export price index of } \\
\text { China }\end{array}$ & & 98.76 & 98.61 & 98.47 & 98.32 & 98.17 & 98.03 & NIESR \\
\hline
\end{tabular}

* National Institute of Economic and Social Research, UK. National Institute Global Econometric Model (NiGEM). http://www. niesr.ac.uk/ (Date of access: 20.10.2015). 
Table 3

Forecasts of foreign factors for the period from 2016 to 2020 (Import growth rate)

\begin{tabular}{|l|c|c|c|c|c|c|c|}
\hline \multicolumn{1}{|c|}{ Partner countries (\%) } & $\mathbf{2 0 1 5 e}$ & $\mathbf{2 0 1 6 f}$ & $\mathbf{2 0 1 7 f}$ & $\mathbf{2 0 1 8 f}$ & $\mathbf{2 0 1 9 f}$ & $\mathbf{2 0 2 0 f}$ & Source \\
\hline World & 3.4 & 4.8 & 5.1 & 5.2 & 5.3 & 5.3 & IMF $^{*}$ \\
\hline Australia & -4.8 & 1.7 & 2 & 2.2 & 2.5 & 3.1 & IMF \\
\hline Cambodia & 8.8 & 11.8 & 11.9 & 9.8 & -1.6 & 9.3 & IMF \\
\hline China & 5.8 & 6.2 & 6.5 & 6.6 & 6.6 & 7 & IMF \\
\hline France & 4.5 & 3.7 & 3.8 & 3.9 & 4.1 & 4.1 & IMF \\
\hline Germany & 4.5 & 5 & 5.4 & 5.5 & 5.6 & 5.6 & IMF \\
\hline Hong Kong & 3.2 & 5.1 & 5.4 & 5.8 & 6.1 & 6.5 & IMF \\
\hline Indonesia & 6.4 & 2.8 & 4.9 & 5.7 & 7.1 & 8 & IMF \\
\hline Italy & 2.1 & 2.4 & 3.1 & 3.3 & 3.4 & 3.4 & IMF \\
\hline Japan & 4.2 & 4.5 & 3.6 & 3 & 2.9 & 3 & IMF \\
\hline Korea & 2.5 & 3.9 & 5.3 & 5.3 & 5.3 & 5.4 & IMF \\
\hline Malaysia & 15.1 & 4.9 & 4.9 & 4.9 & 5.2 & 5.3 & IMF \\
\hline Netherlands & 4.4 & 4 & 3.8 & 3.9 & 3.9 & 3.9 & IMF \\
\hline Philippines & 12.9 & 5 & 5.6 & 6.4 & 6.8 & 7.1 & IMF \\
\hline Singapore & 7.6 & 5 & 5.9 & 7.4 & 7.9 & 8.2 & IMF \\
\hline Thailand & 10.2 & 5.2 & 5.1 & 5.3 & 5.2 & 5.1 & IMF \\
\hline UK & 3.9 & 3.9 & 4.2 & 4.1 & 3.8 & 3.8 & IMF \\
\hline US & 4.6 & 5.2 & 5.7 & 5 & 4.8 & 4.4 & IMF \\
\hline
\end{tabular}

* IMF — International Monetary Fund. http://www.imf.org/ (Date of access: 15.10.2015).

Table 4

Forecasts of domestic factors for the period from 2016 to 2020 (Baseline scenario)

\begin{tabular}{|l|c|c|c|c|c|c|}
\hline \multicolumn{1}{|c|}{ Domestic factors } & $\mathbf{2 0 1 5 e}$ & $\mathbf{2 0 1 6 f}$ & $\mathbf{2 0 1 7 f}$ & $\mathbf{2 0 1 8 f}$ & $\mathbf{2 0 1 9 f}$ & $\mathbf{2 0 2 0 f}$ \\
\hline Nominal exchange rate of Dong to USD & $21,781.88$ & $22,217.52$ & $22,550.78$ & $22,889.04$ & $23,117.93$ & $23,349.11$ \\
\hline Public investment & 170,715 & 180,787 & 190,911 & 201,411 & 211,885 & 222,479 \\
\hline Growth rate (\%) & 6.1 & 5.9 & 5.6 & 5.5 & 5.2 & 5.0 \\
\hline 12 -month lending rate (\%) & 11.5 & 12.5 & 12.5 & 12.5 & 12.5 & 12.5 \\
\hline $\begin{array}{l}\text { Credit to the private sector/GDP at cur- } \\
\text { rent prices }\end{array}$ & 98.99 & 100.41 & 101.91 & 102.3 & 103.4 & 105.05 \\
\hline Rate of devaluation of Dong (\%) & 3 & 2 & 1.5 & 1.5 & 1.0 & 1.0 \\
\hline M2/GDP at current prices (\%) & 75 & 85 & 85 & 90 & 90 & 90 \\
\hline Foreign direct investment & $13,194.10$ & $14,021.37$ & $14,887.89$ & $15,819.88$ & $16,821.27$ & $17,901.20$ \\
\hline $\begin{array}{l}\text { Growth rate (\%) } \\
\text { The depreciation rates by whole econ- } \\
\text { omy and by economic sectors }\end{array}$ & $\begin{array}{l}\text { GSO and unchanged } \\
\text { Gercentage of total budget revenue } \\
\text { spent on education and training, health } \\
\text { care, social security, defence and na- } \\
\text { tional security. }\end{array}$ & $\begin{array}{l}\text { The average percentage of the previous five years of total budget revenue was } \\
\text { spent on these fields }\end{array}$ & 6.18 & 6.33 & 6.42 \\
\hline $\begin{array}{l}\text { Electricity prices for production, busi- } \\
\text { ness, civil use, public service activi- } \\
\text { ties, etc. }\end{array}$ & $\begin{array}{l}\text { Electricity prices in the first three years (2016, 2017, 2018) equal the electric- } \\
\text { ity prices in 2015. The electricity prices in the next two years (2019, 2020) equal } \\
\text { the electricity prices of 2015 multiply by (1 + r), where r is the Consumer Price } \\
\text { Inflation rate of the period 2016-2018 }\end{array}$ \\
\hline
\end{tabular}

Source: [1].

The Vietnam's model was used to find out the consequences of shocks for the Vietnamese economy. The shocks apply to:

- The foreign environment: world demand addressed to Vietnam, foreign prices;

- The government policy: interest rates, money supply, government investment and expenditure.
Specifically, the impact of demand shocks includes the government investment, the expenditure for education, the expenditure for health care, and the expenditure for social security and poverty reduction. The impact of supply shocks includes the 12 months lending rate, the ratio of credit for the private sector and GDP at current prices, the ratio of money supply M2 and GDP at 
Table 5

Forecasts of share in Vietnamese export to the 17 major trade partners for the period from 2016 to 2020 (Baseline scenario)

\begin{tabular}{|l|c|c|c|c|c|c|c|}
\hline Partner countries (\%) & $\mathbf{2 0 1 5 e}$ & $\mathbf{2 0 1 6 f}$ & $\mathbf{2 0 1 7 f}$ & $\mathbf{2 0 1 8 f}$ & $\mathbf{2 0 1 9 f}$ & $\mathbf{2 0 2 0 f}$ & $\mathbf{2 0 1 6 - 2 0 2 0 ~ ( f ) ~}$ \\
\hline Australia & 2.800 & 2.900 & 2.779 & 2.775 & 2.801 & 2.811 & 2.813 \\
\hline Cambodia & 2.515 & 2.537 & 2.524 & 2.517 & 2.520 & 2.523 & 2.524 \\
\hline China & 10.925 & 10.965 & 10.759 & 10.668 & 10.804 & 10.824 & 10.804 \\
\hline France & 1.690 & 1.723 & 1.725 & 1.692 & 1.696 & 1.705 & 1.708 \\
\hline Germany & 3.477 & 3.516 & 3.523 & 3.513 & 3.497 & 3.505 & 3.511 \\
\hline Hong Kong & 3.150 & 2.967 & 3.104 & 3.078 & 3.070 & 3.074 & 3.058 \\
\hline Indonesia & 2.064 & 2.080 & 2.009 & 1.999 & 2.019 & 2.034 & 2.028 \\
\hline Italy & 1.591 & 1.638 & 1.649 & 1.651 & 1.634 & 1.633 & 1.641 \\
\hline Japan & 11.020 & 11.050 & 11.070 & 10.884 & 11.120 & 11.170 & 11.059 \\
\hline Korea & 5.120 & 5.230 & 5.300 & 5.450 & 5.500 & 5.320 & 5.360 \\
\hline Malaysia & 3.590 & 3.536 & 3.671 & 3.619 & 3.587 & 3.601 & 3.603 \\
\hline Netherlands & 2.243 & 2.224 & 2.225 & 2.238 & 2.240 & 2.234 & 2.232 \\
\hline Philippines & 1.780 & 1.930 & 2.050 & 2.170 & 1.916 & 1.969 & 2.007 \\
\hline Singapore & 2.240 & 2.144 & 2.128 & 2.140 & 2.160 & 2.163 & 2.147 \\
\hline Thailand & 2.280 & 2.340 & 2.334 & 2.306 & 2.302 & 2.312 & 2.319 \\
\hline UK & 2.556 & 2.602 & 2.627 & 2.622 & 2.586 & 2.599 & 2.607 \\
\hline US & 18.720 & 18.780 & 18.860 & 18.950 & 19.080 & 19.170 & 18.968 \\
\hline The remaining countries & 22.238 & 21.840 & 21.661 & 21.731 & 21.467 & 21.354 & 21.610 \\
\hline
\end{tabular}

Source: [1].

Table 6

Forecasts of domestic factors for the period from 2016 to 2020 (Target scenario)

\begin{tabular}{|c|c|c|c|c|c|c|}
\hline Domestic factors & $2015 e$ & $2016 f$ & $2017 f$ & $2018 f$ & 2019f & $2020 \mathrm{f}$ \\
\hline $\begin{array}{l}\text { Nominal exchange rate of Dong } \\
\text { to USD }\end{array}$ & $21,781.88$ & $22,435.34$ & $23,108.40$ & $23,801.65$ & $24,515.70$ & $25,251.17$ \\
\hline Public investment & 170,715 & 180,958 & 194,530 & 208,925 & 224,176 & 240,541 \\
\hline Growth rate $(\%)$ & 6.1 & 6 & 7.5 & 7.4 & 7.3 & 7.3 \\
\hline 12-month lending rate $(\%)$ & 11.5 & 12.5 & 12.5 & 12.5 & 12.5 & 12.5 \\
\hline $\begin{array}{l}\text { Credit to the private sector/GDP at } \\
\text { current prices }\end{array}$ & 98.99 & 101.34 & 104.75 & 106.30 & 108.45 & 111.15 \\
\hline Rate of devaluation of Dong (\%) & 3 & 3 & 3 & 3 & 3 & 3 \\
\hline M2/GDP at current prices (\%) & 75 & 90 & 95 & 100 & 100 & 105 \\
\hline Foreign direct investment & $13,194.10$ & $14,183.66$ & $15,389.27$ & $16,774.30$ & $18,334.31$ & $20,076.07$ \\
\hline Growth rate $(\%)$ & 6.3 & 7.5 & 8.5 & 9 & 9.3 & 9.5 \\
\hline $\begin{array}{l}\text { The depreciation rates by whole } \\
\text { economy and by economic sectors }\end{array}$ & \multicolumn{6}{|c|}{ GSO and unchanged } \\
\hline $\begin{array}{l}\text { Percentage of total budget revenue } \\
\text { spent on education and training, } \\
\text { health care, social security, defence } \\
\text { and national security }\end{array}$ & \multicolumn{6}{|c|}{$\begin{array}{l}\text { Reducing } 10 \% \text { of frequent expenditures (equal to } 7 \% \text { of total budget revenue) and } \\
\text { increasing expenditure by } 2 \%, 1 \%, 1 \% \text { and } 3 \% \text { of total revenues for education, } \\
\text { health, social security, and defence \& national security, respectively. }\end{array}$} \\
\hline $\begin{array}{l}\text { Electricity prices for production, } \\
\text { business, civil use, public service } \\
\text { activities, etc. }\end{array}$ & \multicolumn{6}{|c|}{$\begin{array}{l}\text { Electricity prices in the first three years }(2016,2017,2018) \text { equal the electricity } \\
\text { prices in } 2015 \text {. The electricity prices in the next two years }(2019,2020) \text { equals the } \\
\text { electricity prices of } 2015 \text { multiply by }(1+r) \text {, where } r \text { is the Consumer Price Inflation } \\
\text { rate of the period } 2016-2018 \text {. }\end{array}$} \\
\hline
\end{tabular}

Source: [1].

current prices. The impact of foreign trade shocks includes devaluation of the national money (Dong) relative to USD, change of shares in Vietnamese export to trade partners, and the price shock of crude oil [23]. All these shocks have been evaluated using the Vietnam's model.

\subsection{Adjusting Planned Target Indicators}

In order to find out where we are on the way to the destination and can reach it [2] in the process of implementing the plan for medium-term socio-economic development, it is necessary to forecast the plan's target indicators. The target indi- 
Table 7

Forecasts of share to the 17 major trade partners in Vietnamese export for the period from 2016 to 2020 (Target scenario)

\begin{tabular}{|l|c|c|c|c|c|c|c|}
\hline Partner countries (\%) & $\mathbf{2 0 1 5 e}$ & $\mathbf{2 0 1 6 f}$ & $\mathbf{2 0 1 7 f}$ & $\mathbf{2 0 1 8 f}$ & $\mathbf{2 0 1 9 f}$ & 2020f & 2016-2020 (f) \\
\hline Australia & 2.800 & 2.987 & 2.974 & 2.969 & 2.997 & 3.008 & 2.987 \\
\hline Cambodia & 2.515 & 2.537 & 2.524 & 2.517 & 2.520 & 2.523 & 2.524 \\
\hline China & 10.925 & 9.868 & 9.145 & 9.068 & 9.183 & 9.200 & 9.293 \\
\hline France & 1.690 & 1.757 & 1.811 & 1.776 & 1.781 & 1.790 & 1.783 \\
\hline Germany & 3.477 & 3.547 & 3.700 & 3.688 & 3.672 & 3.681 & 3.657 \\
\hline Hong Kong & 3.150 & 2.967 & 3.104 & 3.078 & 3.070 & 3.074 & 3.058 \\
\hline Indonesia & 2.064 & 2.080 & 2.009 & 1.999 & 2.019 & 2.034 & 2.028 \\
\hline Italy & 1.591 & 1.671 & 1.731 & 1.733 & 1.716 & 1.714 & 1.713 \\
\hline Japan & 11.020 & 11.382 & 11.845 & 11.646 & 11.898 & 11.952 & 11.744 \\
\hline Korea & 5.120 & 5.387 & 5.671 & 5.832 & 5.885 & 5.692 & 5.693 \\
\hline Malaysia & 3.590 & 3.642 & 3.928 & 3.872 & 3.838 & 3.853 & 3.827 \\
\hline Netherlands & 2.243 & 2.269 & 2.337 & 2.350 & 2.352 & 2.346 & 2.331 \\
\hline Philippines & 1.780 & 1.930 & 2.050 & 2.170 & 1.916 & 1.969 & 2.007 \\
\hline Singapore & 2.240 & 2.208 & 2.277 & 2.290 & 2.312 & 2.314 & 2.280 \\
\hline Thailand & 2.280 & 2.340 & 2.334 & 2.306 & 2.302 & 2.312 & 2.319 \\
\hline UK & 2.556 & 2.654 & 2.758 & 2.753 & 2.715 & 2.729 & 2.722 \\
\hline US & 18.720 & 19.343 & 20.180 & 20.277 & 20.416 & 20.512 & 20.146 \\
\hline $\begin{array}{l}\text { The remaining } \\
\text { countries }\end{array}$ & 22.238 & 21.432 & 19.621 & 19.678 & 19.407 & 19.297 & 19.887 \\
\hline
\end{tabular}

Table 8

Some forecasts of the baseline and target scenarios

\begin{tabular}{|c|c|c|c|c|c|c|c|c|c|c|}
\hline \multirow{2}{*}{$\begin{array}{l}\text { Indicators } \\
\text { Growth rate of }(\%)\end{array}$} & \multicolumn{5}{|c|}{ Baseline scenario (\%) } & \multicolumn{5}{|c|}{$\begin{array}{c}\text { Target scenario vs. Baseline scenario (\% } \\
\text { point) }\end{array}$} \\
\hline & 2016 & 2017 & 2018 & 2019 & 2020 & 2016 & 2017 & 2018 & 2019 & 2020 \\
\hline Gross Domestic Product (GDP) & 6.29 & 6.34 & 6.48 & 6.78 & 7.02 & 0.27 & 0.74 & 1.06 & 1.25 & 1.81 \\
\hline GDP of the primary industry & 2.3 & 2.7 & 2.75 & 3.05 & 3.22 & 0.26 & 0.50 & 0.70 & 0.90 & 0.99 \\
\hline GDP of the secondary industry & 7.5 & 7.6 & 7.61 & 7.85 & 8.05 & 0.28 & 0.84 & 1.19 & 1.37 & 2.08 \\
\hline GDP of the tertiary industry & 6.71 & 6.45 & 6.49 & 6.81 & 7.05 & 0.27 & 0.74 & 1.06 & 1.26 & 1.82 \\
\hline Population & 1.068 & 1.068 & 1.068 & 1.067 & 1.067 & 0 & 0 & 0 & 0 & 0 \\
\hline Employment & 0.98 & 1.03 & 1.53 & 1.87 & 2.09 & 0.2 & 0.08 & 0.12 & 0.10 & 0.07 \\
\hline Average income & 5.16 & 5.45 & 5.89 & 6.02 & 6.26 & 0.62 & 1.74 & 2.59 & 3.2 & 4.12 \\
\hline Household Consumption & 5.56 & 5.79 & 6.10 & 6.22 & 6.72 & 0.35 & 1.48 & 1.86 & 2.43 & 3.3 \\
\hline Public consumption & 7.74 & 7.85 & 7.76 & 7.79 & 7.92 & 0 & 0.13 & 0.38 & 0.53 & 0.61 \\
\hline Final consumption & 5.75 & 5.98 & 6.25 & 6.37 & 6.83 & 0.32 & 1.37 & 1.73 & 2.25 & 3.05 \\
\hline Total Investment & 9.84 & 12.29 & 12.28 & 12.16 & 12.14 & 0.49 & 1.01 & 1.82 & 1.88 & 2.06 \\
\hline Foreign investment & 9.5 & 10.12 & 10.17 & 10.23 & 10.21 & 1.21 & 2.31 & 2.75 & 3.02 & 3.16 \\
\hline Private Investment & 9.81 & 12.85 & 12.91 & 13.02 & 12.84 & 0.52 & 0.78 & 2.15 & 2.51 & 2.79 \\
\hline State Investment & 10.22 & 12.03 & 12.31 & 12.65 & 12.74 & 0.02 & 0.5 & 0.99 & 0.58 & 0.75 \\
\hline Total accumulation of assets & 9.98 & 10.64 & 11.12 & 11.54 & 12.00 & -0.05 & -0.04 & 0 & 0.18 & 0.34 \\
\hline Total export & 12.5 & 12.8 & 12.7 & 13.06 & 13.5 & 1.3 & 2.3 & 2.7 & 2.95 & 3.27 \\
\hline Total import & 10.7 & 12.2 & 12.6 & 12.67 & 13.04 & 0.9 & 2.15 & 2.87 & 2.93 & 3.04 \\
\hline Electricity demand & 11.03 & 13.26 & 13.69 & 13.76 & 13.99 & 0.75 & 1.17 & 0.83 & 0.94 & 0.78 \\
\hline Consumer Price Index (CPI) & 103.20 & 103.70 & 104.17 & 104.32 & 104.21 & 3.11 & 3.45 & 3.12 & 1.57 & 1.78 \\
\hline $\begin{array}{l}\text { GDP deflator (constant prices } \\
\text { 2010) }\end{array}$ & 1.49 & 1.52 & 1.57 & 1.63 & 1.69 & 0.002 & 0.010 & 0.020 & 0.028 & 0.043 \\
\hline Export Price Index & 101.99 & 102.95 & 103.12 & 103.82 & 103.98 & 1.08 & 0.98 & 1.17 & 1.19 & 1.56 \\
\hline Import Price Index & 101.35 & 102.39 & 102.91 & 103.43 & 103.51 & 1.27 & 1.02 & 1.34 & 1.37 & 1.87 \\
\hline $\begin{array}{l}\text { Budget Revenue (\% of GDP at } \\
\text { current prices) }\end{array}$ & 22.29 & 22.11 & 21.87 & 21.83 & 22.27 & 1.7 & 1.85 & 2.1 . & 2.25 & 2.07 \\
\hline
\end{tabular}


cators can be forecasted by the Vietnam's model. Based on these forecasts, it is easy to adjust some target indicators.

\section{The Model's Forecast Quality}

In this section, I compare the actual statistical data of some macro-economic variables for 2016 and 2017 with the ex-ante forecasts of these variables according to the baseline and target scenarios. I present comparative results in Table 9.

From the Table 9 and Figure 3 depicted below, it can see that the actual economic growth rates are close to the forecasts. The actual rates are located in the middle of the baseline scenario and the target scenario excepting the growth rate of the primary industry. In 2016, the actual growth rate of this industry is lower than the forecasted by close 1-percentage point (\% point). In this year, the production in the primary industry encountered many difficulties, including natural disasters, floods and storms; the problems with livestock products' export (that were the sold below production cost), etc. However, in 2016, due to the economy's high growth, the average income of the people was higher than the forecasted. This is the main reason why the actual public, household and final consumptions were higher than the forecasted according to both scenarios.

The forecasts of export and import growth rates compared with its actual growth rates in 2016 and 2017 were inverse to one another. In 2016, the growth rates of both total export and total import were much lower than the forecasted, but in 2017, they were much higher (Figure 3). In 2016, the export of Vietnam faced many difficulties. The government implemented some policies to limit the trade deficit, so the actual growth rates of export and import decreased very strongly and were the lowest in the last 10 years. However, in 2017, the growth rate of export as well as of import greatly increased. The increase was due to the development of Vietnam's private economy that the ruling Party and State considered a driving force of the economy's development. The Government has implemented many solutions to create a favourable environment for production and busi-

Actual data vs. forecasts in 2016, 2017

Table 9

\begin{tabular}{|c|c|c|c|c|c|c|}
\hline \multirow[t]{2}{*}{ Indicators } & \multicolumn{2}{|c|}{ Actual (\%) } & \multicolumn{2}{|c|}{$\begin{array}{l}\text { Actual vs. Baseline } \\
\text { Sce. (\% point) }\end{array}$} & \multicolumn{2}{|c|}{$\begin{array}{c}\text { Actual vs. Target Sce. } \\
\text { (\% point })\end{array}$} \\
\hline & 2016 & 2017 & 2016 & 2017 & 2016 & 2017 \\
\hline \multicolumn{7}{|l|}{ Growth rate of (\%) } \\
\hline Gross Domestic Product (GDP) & 6.21 & 6.81 & -0.08 & 0.47 & -0.35 & -0.27 \\
\hline GDP of the primary industry & 1.36 & 2.90 & -0.94 & 0.2 & -1.2 & -0.3 \\
\hline GDP of the secondary industry & 7.57 & 8.00 & 0.07 & 0.4 & -0.21 & -0.44 \\
\hline GDP of the tertiary industry & 6.98 & 7.44 & 0.27 & 0.99 & 0 & 0.25 \\
\hline Population & 1.07 & 1.07 & 0.002 & 0.002 & 0.002 & 0.002 \\
\hline Employment & 0.88 & 0.79 & -0.1 & -0.24 & -0.3 & -0.32 \\
\hline Average income & 5.38 & 5.68 & 0.22 & 0.23 & -0.4 & -1.51 \\
\hline Household Consumption & 8.31 & NA & 2.75 & NA & 2.4 & NA \\
\hline Public consumption & 10.38 & NA & 2.64 & NA & 2.64 & NA \\
\hline Final consumption & 8.49 & NA & 2.74 & NA & 2.42 & NA \\
\hline Total Investment & 9.6 & 12.1 & -0.24 & -0.19 & -0.73 & -1.2 \\
\hline Foreign investment & 10.0 & 12.8 & 0.5 & 2.68 & -0.71 & 0.37 \\
\hline Private Investment & 10.7 & 16.8 & 0.89 & 3.95 & 0.37 & 3.17 \\
\hline State Investment & 8.3 & 6.7 & -1.92 & -5.33 & -1.94 & -5.83 \\
\hline Total accumulation of assets & 9.71 & NA & -0.27 & NA & -0.22 & NA \\
\hline Total export & 9.00 & 16.70 & -3.5 & 3.9 & -4.8 & 1.6 \\
\hline Total import & 5.23 & 16.19 & -5.47 & 3.99 & -6.37 & 1.84 \\
\hline Electricity demand & 11.5 & 9.7 & 0.47 & -0.27 & -0.28 & -0.49 \\
\hline Consumer Price Index (CPI) & 102.66 & 103.53 & -0.54 & -0.17 & -3.65 & -3.62 \\
\hline GDP deflator (constant prices 2010) & 1.47 & 1.535 & -0.02 & 0.015 & -0.022 & 0.005 \\
\hline Export Price Index & 98.29 & 102.93 & -3.7 & -0.02 & -4.78 & -1 \\
\hline Import Price Index & 94.65 & 102.57 & -6.7 & 0.18 & -7.97 & -0.84 \\
\hline Budget Revenue (\% of GDP at current prices) & 24.46 & 24.7 & 2.17 & 2.59 & 0.47 & 0.74 \\
\hline
\end{tabular}

Source: GSO and the author's forecasts. 


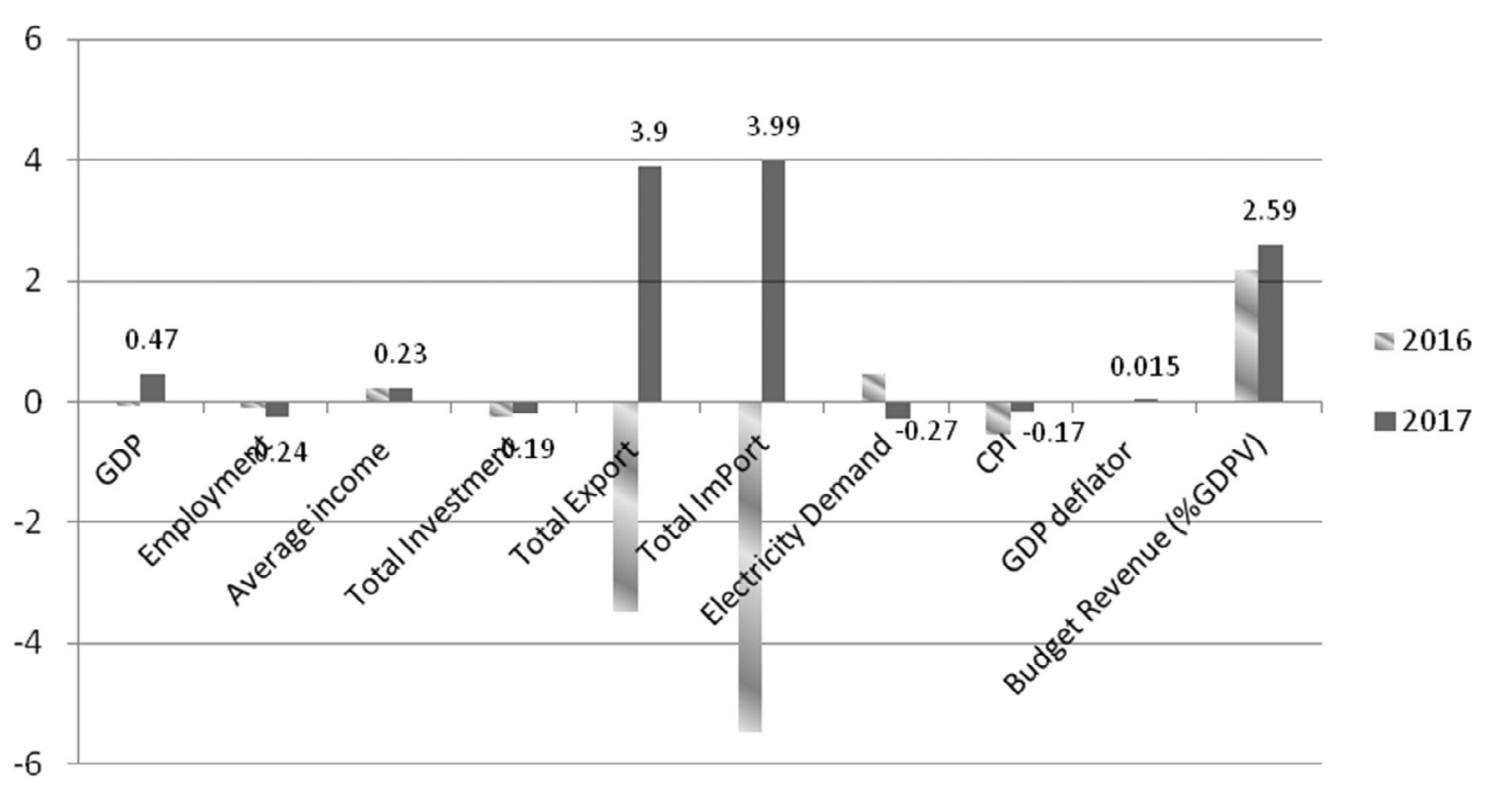

Fig. 3. Actual data vs. Baseline scenario forecasts (\% point)

ness activities, and to remove difficulties for enterprises, especially small and medium. This led to the great increase in private and foreign investments, promoting the production development and economic growth. The economic growth rate, the growth rates of export and import in this year were the highest in the last 10 years.

The specificity of the Vietnam's economy in 2016 and 2017 is high economic growth and low inflation. The actual Consumer Price Index (CPI) being lower than the two forecast scenarios implies that the Vietnam's model may not fully include the factors reflecting the economy's efficiency.

The ratio of actual budget revenue and GDP in 2016 and 2017 were quite high and higher than the forecasted (Figure 3). This suggests that when forecasting the budget revenue, it is necessary to combine forecasts from the Vietnam's model and from other statistical models in the Ministry of Finance as well as from this model with application of the judgmental methods.

\section{Conclusions and Discussions}

The paper has presented five most important applications and the initial assessments of the accuracy of the Vietnam's model. The forecast process for socio-economic development planning involves the participation of many ministries and local governments, therefore the forecasts' synthesis, validation, combination and balance from many sources are of crucial importance for this process. The paper has shown that the Vietnam's model facilitates such activities. Expert surveys or small group meetings can easily add domain knowledge to the Vietnam's model. The paper has highlighted the ability of the Vietnam's model to generate forecasts for socio-economic development planning and to monitor and evaluate the implementation of this plan. Moreover, the model can be used for building forecast scenarios, simulating and evaluating impacts of some economic shocks and policies, adjusting planned target indicators. The Vietnam's model aims to depoliticise the forecasting process and improve communication between economic experts, forecasters, and planner.

Comparison between the ex-ante forecasts obtained after applying the baseline and target scenarios using only the Vietnam's model and actual data for 2016 and 2017 shows that the forecast error is likely to occur for the economic variables, mainly in the field of trade and finance. Among other aspects, two important factors may cause this situation:

- Foreign and domestic factors are no longer the same as the original assumptions. For example, in 2016 and 2017, the 12-month lending interest rate was only around $10.5-11 \%$, unlike the assumed rate of $12.5 \%$ (even though in previous years lending interest rate was very high, even up to $16 \%$ per year), or the world oil price was different from NIER's forecast, etc.

- The policies of the Vietnamese State have changed rather strongly in the last two years, especially those related to private economic development, state administrative reform, building of tectonic government. The Vietnam's model has not adequately reflected some of the Government's breakthrough economic policies, as the domain knowledge was not implemented for adjusting and combining forecasts obtained from this model. 
Overcoming these two causes might improve the model's forecast accuracy and ensure the socio-economic development planning for the period from 2021 to 2025 in Vietnam.

In addition, analysis of the structure of the Vietnam's model shows that the forecast accuracy of the Consumer Price Index (CPI) and the economic growth rate of the primary, secondary and tertiary industries strongly influences the forecast accuracy of many other economic indicators. Therefore, it is necessary to build a high frequency year model using the approaches mentioned in $[24,25]$ to forecast CPI and GDP of the aforementioned industries. Such model can be considered as a supporting forecast model for the Vietnam's model.

\section{Acknowledgements}

I would like to Prof. Minh, N. K., Assoc. Prof. Tuan, B. Q., PhD. Duc, L. V. had have many valuable comments for forecast scenarios and forecasted results; to thank masters: Hao, D. T., Ngoc, B. B., Lam, D. V., Huong, L. T., Nhuong, C. T., Anh, L. Q., Hien, N. M., Minh, T. H., Linh, N. H. and Dung, N. V. from the National Centre for Socio-Economic Information and Forecast, Ministry of Planning and Investment of Vietnam supported in testing the built model.

I also would like to thank the anonymous referees for their comments and suggestions for revising this paper. This work was funded by Vietnam's Ministry of Science and Technology, Contract No. 18/2014/HĐ-NĐT.

\section{References}

1. Thanh D. V. (2017). Báo cáo tông hợp: Nghiên cúu phương pháp dư báo kinh tế - xã hội trung hạn ở Liên bang Nga và khả năng ûng dụng vào Việt Nam [Synthesis Report: Research on medium-term socio-economic forecasting methodologies in the Russian Federation and its applicability to Vietnam]. Vietnam: National Library of Science and Technology, 359. (In Vietnamese)

2. Thanh, D. V. (2019). Macro econometric model for medium-term socio-economic development planning in Vietnam - Part 1: Structure of the model. Ekonomika regiona [Economy of region], 15(1), 121-136.

3. Kirichenko, I. A. \& Smirnov, A. V. (2015). Forecasting procedures for strategic planning in the Russian Federation. Workshop: Forecasting methodology for medium-term Socio-economic development planning in the Russian Federation and its applicability to Vietnam. Jun 25, 2015, Hanoi.

4. Strizhkova, L. A. (2012). K Voprosu Ucheta Sistemnykh Sviazei pri Sostavlenii Makroekonomicheskogo Prognoza [The role of system relations, in macroeconomic forecasts]. Sbornik Nauchnykh Trudov IMEI [Proceedings of the Institute of Macroeconomic Research], 2, 26-78. (In Russ.)

5. Yekimova, K.V., Savelyeva, I. P. \& Tsalo I. M. (2016). Otsenka vliyaniya izmeneniy konyuktury mirovykh rynkov na regionalnye protsessy [Assessment of the Impact of the Changes in the Situation of the World Markets on the Regional Processes]. Ekonomika regiona [Economy of Region], 12(3), 670-683. (In Russ.)

6. Zhuravskly, V. P. (2012). O postanovke modeli prognozirovaniya indeksov-deflyatorov vypuska v uvyazke s dannymi stsenarnykh usloviy [Forecast Models of output deflator index as part of scenario conditions]. Sbornik Nauchnykh Trudov IMEI [Proceedings of the Institute of Macroeconomic Research], 2, 154-172. (In Russ.)

7. Kirichenko, I. A. \& Smirnov, A.V. (2013). Vliyanie makroekonomicheskikh pokazateley na formirovanie investitsionnykh protsessov v ekonomike [Influence of Macroeconomic Indicators on the development of investment processes in the economy]. Sbornik Nauchnykh Trudov IMEI [Proceedings of the Institute of Macroeconomic Research], 2, 7- 59. (In Russ.)

8. Kuranov, A. G. (2012). Analiz ustoychivosti reshniy modeli mezhotraslevogo balansa [Analysis of solution stability in IO models]. Sbornik Nauchnykh Trudov IMEI [Proceedings of the Institute of Macroeconomic Research], 2, 79-94. (In Russ.)

9. Slobodyanik, S. N. (2012). Metodicheskie problem kompleksnoy otsenki vliyaniya faktora energopotrebleniya na ekonomicheskiy rost i puti ikh resheniya [Methodological issues of relationship between energy consumption and economic growth estimations]. Sbornik Nauchnykh Trudov IMEI [Proceedings of the Institute of Macroeconomic Research], 2, 219-238. (In Russ.)

10. Shen, L. (2000). China’s Macro Economic Annual Model. In: L. R. Klein, I. Shinichi (Eds.), Econometric Modeling of China (pp. 307-319). Singapore: World Scientific Publishing Co. Pte. Ltd.

11. Yoshihisa, I. (2000). ICSEAD's Econometric Model of the Chinese Economy. In: L. R. Klein, I. Shinichi (Eds.), Econometric Modeling of China (pp. 68-150). Singapore: World Scientific Publishing Co. Pte. Ltd.

12. Youcai, L. (2000). China's economic model for project FAIR. In: L. R. Klein, I. Shinichi (Eds.), Econometric Modeling of China (pp. 201-245). Singapore: World Scientific Publishing Co. Pte. Ltd.

13. Rapach, D. E., Strauss, J. K. \& Zhou, G. (2010). Out-of-sample equity premium prediction: combination forecasts and links to the real economy. Review of Financial Studies, 23, 821-862.

14. Franses, P. H. (2014). Expert adjustments of model forecasts: Theory, practice and strategies for improvement. Cambridge: Cambridge University Press, 144.

15. Lawrence, M., Goodwin, P., O'Connor, M. \& Onkal, D. (2006). Judgmental Forecasting: A Review of Progress Over the Last 25 Years. International Journal of Forecasting, 22(3), 493-518.

16. Edmundson, R. H. (1990). Decomposition: A strategy for judgmental forecasting. Journal of Forecasting, 9, 305-314.

17. Timmermann, A. (2006). Forcast combinations. In: G. Elliott, C. W. J. Granger, A. Timmermann (Eds.), Handbook of economic forecasting, vol. 1 (pp. 134-197). Amsterdam: Elsevier. 
18. Armstrong, J. \& Green, K. C. (2018) Forecasting methods and principles: Evidence-based checklists, Journal of Global Scholars of Marketing Science, 28(2), 103-159. DOI: 10.1080/21639159.2018.1441735.

19. Fildes, R., Goodwin, P., Lawrence, M. \& Nikolopoulos, K. (2009). Effective forecasting and judgmental adjustments: An empirical evaluation and strategies for improvement in supply-chain planning. International Journal of Forecasting, 25 , $3-23$.

20. Lim, J. S. \& O’Connor, M. (1995). Judgemental adjustment of initial forecasts: Its effectiveness and biases. Journal of Behavioral Decision Making, 8, 149-168.

21. Armstrong, J. S. \& Collopy, F. (1998). Integration of statistical methods and judgment for time series forecasting: Principles from empirical research. In: G. Wright, \& P. Goodwin (Eds.), Forecasting with judgment (pp. 269-293). Wiley.

22. Deschamps, E. (2004). The impact of institutional change on forecast accuracy: A case study of budget forecasting in Washington State. International Journal of Forecasting, 20(4), 647-657. DOI: 10.1016/j.ijforecast.2003.11.009.

23. Kilian, L. (2008). The Economic Effects of Energy Price Shocks. Journal of Economic Literature, 46(4), 871-909.

24. Klein, L. R. (2009). Background to national economic forecasts and the high-frequency model of the USA. In: $L$. $R$. Klein (Ed.), The Making of National Economic Forecasts (pp. 1-26). Cheltenham, UK; Northampton, Massachusetts, USA: Edward Elgar.

25. Andrei, R. (2009). Short-term forecasting of key indicators of the German economy. In: L. R. Klein (Ed.), The Making of National Economic Forecasts (pp. 121-148). Cheltenham, UK; Northampton, Massachusetts, USA: Edward Elgar.

\section{Author}

Thanh Do Van - Associate Professor, Nguyen Tat Thanh University (300A Nguyen Tat Thanh Str., Ward 13, District 4, 72820, Ho Chi Minh, Vietnam; e-mail: dvthanh@ntt.edu.vn). 